\title{
How Did Arius Learn from Asterius? On the Relationship between the Thalia and the Syntagmation
}

\author{
by MARK DELCOGLIANO \\ University of St Thomas, St Paul \\ E-mail: mark.delcogliano@stthomas.edu
}

In the De decretis Athanasius claims that Arius 'copied' and 'learned' from Asterius. This study explores how this could have happened by arguing that in the writing of his Thalia Arius was influenced by Asterius' Syntagmation. Besides complicating the literary and theological relationship between Arius and Asterius, this reconstruction provides the clearest evidence for the new perspective on Arius which has emerged in recent revisionist scholarship, and which argues that he is best understood as embedded within a theological tradition and as a catalysing participant in its efforts to articulate a theological vision. By dating the Syntagmation to about 322 and the Thalia to about 323 this study also gives qualified support to Rowan Williams's dating of some pre-Nicene events and discredits a recent attempt to position Asterius as having had a formative influence on Arius.

rius has been knocked from his heresiarchal throne in recent his-
toriography on the controversy that bears his name. While previous
generations viewed Arius as the originator and inspiration of a

Dok = Athanasius Werke, III/ 1, Lieferung 3: Dokumente zur Geschichte des arianischen Streites, ed. Hanns Christof Brennecke, Uta Heil, Annette von Stockhausen and Angelika Wintjes, Berlin-New York 2007; NPNF = Nicene and Post-Nicene Fathers; Urk= Athanasius Werke, III/1, Lieferung 1-2: Urkunden zur Geschichte des arianischen Streites, 3I8-328, ed. Hans-Georg Opitz, Berlin-Leipzig 1934-5

Earlier versions of this essay were presented at the Seventeenth International Conference on Patristic Studies at Oxford University in August 2015, and at a meeting of the Minnesota Association for Patristic Studies (MAPS) in February 2016. I am grateful for the comments that I received on these occasions, as well as for the feedback on later drafts offered by Lewis Ayres, Matthew Crawford, Rebecca Lyman, Adam Ployd and Andrew Radde-Gallwitz. 
tradition of theology that lasted for decades after his death, revisionist scholarship of the last fifty years has to various degrees expelled Arius from this regnant position. ' '[T] he direction of recent work', writes Lewis Ayres, 'has been to focus on Arius as a catalyst for a controversy within which his particular theology rapidly becomes marginal.' ${ }^{2}$ The best perspective on Arius that has emerged within recent revisionist scholarship is to view him as embedded within a theological tradition shaped by third-century concerns that is attempting to re-express and revise itself in an early fourthcentury context, 3 and furthermore as an interlocutor within an ecclesiastical alliance whose adherents were to varying extents committed to and in debate over this same tradition. ${ }^{4}$ One goal of this study is to demonstrate how Arius' relationship with Asterius, or more precisely, the relationship

${ }^{1}$ On recent historiographical trends in the study of Arius see R. P. C. Hanson, The search for the Christian doctrine of God: the Arian controversy, $3^{I}{ }^{8}-3{ }^{8} A D$, Edinburgh 1988, pp. xvii-xxi, 123-8; Rowan Williams, Arius: heresy and tradition, rev. edn, Grand Rapids, Mr 2001, 1-25; Lewis Ayres, Nicaea and its legacy: an approach to fourth-century Trinitarian theology, Oxford 2004, 1 1-20, 56-7; John Behr, The Nicene faith, Crestwood 2004, 8-16, 21-36; and Rebecca Lyman, 'Arius and Arians', in Susan Ashbrook Harvey and David G. Hunter (eds), The Oxford handbook of early Christian studies, Oxford 2008, 237-57. On trends through the mid-twentieth century see Rudolf Lorenz, Arius judaizans? Untersuchungen zur dogmengeschichtlichen Einordung des Arius, Göttingen 1980, 23-36; Michael Slusser, 'Traditional views of late Arianism', in Michel R. Barnes and Daniel H. Williams (eds), Arianism after Arius: essays on the development of the fourth century Trinitarian conflicts, Edinburgh 1993, 3-30; and Maurice Wiles, Archetypal heresy: Arianism through the centuries, Oxford 1996.

${ }^{2}$ Ayres, Nicaea and its legacy, 12 n. 3. Maurice Wiles ends his classic essay ('Attitudes to Arius in the Arian Controversy', in Barnes and Williams, Arianism After Arius, 31-43) with these memorable lines: 'the figure of Arius was not perhaps, in fact, very important to any of those known by one of the various expansions of his name [for example, semiArians and neo-Arians]. And to Athanasius he was not so much a person to be refuted, as a discredited name with which to undermine others ... Arius was dead before Athanasius embarked on any large scale theological debate of the issues that Arius had raised. And then his real quarrel was with the living. The dead Arius was not even a whipping boy, but a whip'.

3 Of course, what these concerns were remains highly debated. For example, in Arius judaizans? Lorenz posited Christological concerns, whereas in Early Arianism: a view of salvation, Philadelphia 1981, Robert C. Gregg and Dennis E. Groh argued that soteriological concerns chiefly motivated Arius. In contrast, in Arius, Williams placed more emphasis on Arius' cosmological concerns.

4 For example, Arius is surely to be included among those who espoused what Joseph T. Lienhard, calls a tradition of 'dyohypostatic' theology: Contra Marcellum: Marcellus of Ancyra and fourth-century theology, Washington, DC 1999, 28-46. Ayres places Arius in the 'theological trajectory' that he labels 'Eusebians', along with Eusebius of Nicomedia, Asterius and Eusebius of Caesarea: Nicaea and its legacy, 52-61. Khaled Anatolios catagorises Arius as one of the 'Trinitarian theologians of the unity of the will', along with Asterius, Eusebius of Caesarea and Eunomius of Cyzicus: Retrieving Nicaea: the development and meaning of Trinitarian doctrine, Grand Rapids, Mi 201 1, 41-79. 
between Arius' Thalia and Asterius' Syntagmation, is one of the clearest pieces of evidence for this new perspective on Arius.

Establishing the chronology of the events and documents related to the controversy over Arius before Nicaea is notoriously difficult. ${ }^{5}$ Still, another goal of this study is to give qualified support to Rowan Williams's proposal regarding the dating and circumstances of the Thalia of Arius by drawing attention to a few Athanasian passages, evidence that has hitherto been mostly neglected and that also demonstrates the intra-Eusebian debate over a shared theological tradition in which Arius participated. ${ }^{6}$ While the Thalia is but one document among many that survive (at least in fragments) from before the Council of Nicaea whose precise dates and circumstances of composition are contested, it is one of only a handful authored by Arius himself and a crucial text for understanding the course of controversy over Arius and the development of his theology.7 Furthermore, no one has ever tried to date the Syntagmation of Asterius more specifically than simply to before the Council of Nicaea; accordingly, this study attempts for the first time to date this important document more precisely, thereby facilitating a clearer view of the sequence of events in the preNicene controversy over Arius and Asterius' involvement in it.

5 The chronology of Eduard Schwartz was foundational in the early twentieth century: 'Die Dokumente des arianischen Streits bis 325', in his Gesammelte Schriften, III: Zur Geschichte des Athanasius (1905), Berlin 1959, 11 1 -68. However, it was gradually supplanted by the chronology of Hans-Georg Opitz: 'Die Zeitfolge des arianischen Streites von den Anfängen bis zum Jahr 328', Zeitschrift für die neutestamentliche Wissenschaft xxxiii (1934), 131-59; it was adopted, for example, in Hanson, The search, 129-38. Rowan Williams put forward a drastically revised chronology that has become the touchstone of all further debates: Arius, $4^{8-81}$. Other notable chronologies include Manlio Simonetti, La crisi ariana nel IV secolo, Rome $1975,25^{-41}$, and Winrich Löhr, 'Arius reconsidered (part 1)', Zeitschrift für Antikes Christentum ix (2006), 524-6o. The relevant documents from before about 345 are helpfully collected in Urk and Dok.

6 I use 'Eusebian' in contrast to the Athanasian usage deconstructed by David Gwynn in The Eusebians: the polemic of Athanasius of Alexandria and the construction of the 'Arian Controversy', Oxford 2007, and in line with Lienhard, Contra Marcellum, 34-5, and Ayres, Nicaea and its legacy, $5^{2}$, to name the ad hoc alliance of eastern bishops and theologians initially formed around the figures of Eusebius of Nicomedia and Eusebius of Caesarea. The alliance emerged when several eastern bishops rallied around Arius in common cause against what they deemed to be Alexander of Alexandria's doctrinal innovations and his mistreatment of Arius. But they did not agree with Arius' theology in every detail, and there were theological differences among them. See also n. 8 below.

7 The verbatim fragments of the Thalia are one of the most reliable sources for retrieving the theology of Arius, in addition to his three extant letters. The Thalia fragments are preserved mainly in Athanasius, De synodis 15.3 , but also at the beginning of Contra Arianos 1.5, and there are also two otherwise unattested lines in Contra Arianos 1.6. See G. C. Stead, 'The Thalia of Arius and the testimony of Athanasius', JTS n.s. xxix (1978), 20-52; M. L. West, 'The metre of Arius' Thalia', JTS n.s. xxxiii (1982), 98-105; Williams, Arius, 95-9; and Winrich Löhr, 'Arius reconsidered (part 2)', Zeitschrift für Antikes Christentum x (2006), $121-57$. See also n. $3^{8}$ below. 
One of the features of the Eusebian alliance was mutual defence. ${ }^{8}$ Athanasius repeatedly presents Asterius as the advocate (бvvíropos) of Arianism. 9 This is usually taken to mean that he judged Asterius to be prominent among those Eusebians who supported Arius' cause in the years leading up to the Council of Nicaea and afterwards. It is usually assumed that Arius, if not a source, was at least a foil for Asterius: Asterius defended Arius even as he developed his thought. ${ }^{10}$ Athanasius himself is generally vague about their relationship. In most cases he accuses both of teaching the same things without mentioning influence in one direction or the other. ${ }^{11}$ But in two passages in De decretis (sections 8 and 20) Athanasius claims that Arius copied from Asterius. These passages have rarely been cited in studies of Arius or Asterius, especially recently, and when they have it is usually with little or no comment. ${ }^{12}$ Based in part on these passages, however, Markus Vinzent has suggested

${ }^{8}$ I have explored the concept of an 'ecclesiastical alliance' in general and the traits of the 'Eusebian alliance' in particular in a number of articles: Mark DelCogliano, 'Eusebian theologies of the Son as image of God before 341', Journal of Early Christian Studies xiv (2006), 459-84; 'The Eusebian alliance: the case of Theodotus of Laodicea', Zeitschrift für Antikes Christentum xii (2008), 250-66; 'George of Laodicea: a historical reassessment', this Journal lxii (2011), 667-92; and 'Eusebius of Caesarea's defense of Asterius of Cappadocia in the anti-Marcellan writings: a case study of mutual defense within the Eusebian alliance', in Aaron Johnson and Jeremy Schott (eds), Eusebius of Caesarea: traditions and innovations, Washington, DC 2013, 263-87.

9 Athanasius, Contra Arianos 1.30; 1.32; 3.2; 3.60; De synodis 20.1. The texts of Athanasius are cited according to the Athanasius Werke editions: Orationes contra Arianos was edited by Karin Metzler and Kyriakos Savvidis, in Athanasius Werke, I/1: Die dogmatischen Schriften, ed. Martin Tetz, Berlin 1996-2000, 109-381. De decretis can be found in Hans-Georg Opitz, Athanasius Werke, II/1: Die Apologien, Berlin-Leipzig 1940, 1-45, and in De synodis in Opitz, Die Apologien, 231-78.

${ }^{10}$ For example, after discussing five original contributions of Asterius in the Syntagmation (pp. 29-34), Thomas A. Kopecek writes that 'So we see that the Cappadocian layman, sophist, and Lucianist was determined both to refine Arius' position wherever he thought it required refinement and to develop its exegetical underpinnings wherever possible': A history of neo-Arianism, Cambridge 1979, 34. Anatolios presents Asterius as both a 'continuator' and a 'reviser' of Arius: Retrieving Nicaea, 53-9.

${ }^{11}$ On this point, see below.

${ }^{12}$ For example, De decretis 8 is cited in discussions of the dating of the Syntagmation and its influence on the Thalia is suggested without further exploration of the relationship between these two texts by Louis-Sébastien Le Nain de Tillemont, Mémoires pour servir à l'histoire ecclésiastique des six premiers siècles, vi, Venice 1732, 292, 751 n. 21, and by Gustave Bardy, Recherches sur saint Lucien d'Antioche et son école, Paris 1936, 320-1. Others cite De decretis 8, stating without much further comment that Arius made use of the work of Asterius; for example, Theodor Zahn, Marcellus von Ancyra, Gotha 1867, 39; Wilhlem Köllig, Geschichte der arianischen Häresie, i, Gütersloh 1874, 99; Adolph Harnack, History of dogma, iv, Boston 1907, 20 n. 2; and Timothy D. Barnes, Constantine and Eusebius, Cambridge, MA 1981, 241. With a few exceptions, recent scholarship does not even cite, let alone discuss, De decretis 8 and 20; in contrast, older scholarship at least cited these passages. 
that Asterius might have had a formative influence on Arius. ${ }^{13}$ These passages contribute to his view that what came to be known as 'Arianism' is really the theology of Asterius. ${ }^{14}$ In the De decretis passages Athanasius claims that Arius learned very precise things from Asterius, first, specific language about the Son's ministerial and servile role in creation, and, second, a series of biblical passages useful for arguing against the uniqueness of the Son's relation to God. And there could well be other things that Arius learned from Asterius but which Athanasius did not mention. But I do not think that Asterius was as formative for Arius as Vinzent suggests. I argue that, if these De decretis passages are trustworthy, ${ }^{15}$ Asterius' influence on Arius only happened once the controversy over him had spread throughout the East.

I want to explore a historical question: how could Arius have learned from Asterius? They were probably of the same generation, coming to adulthood in the late third century. It is unlikely that they ever met in person, and there is certainly no record of such a meeting. They came from different parts of the world, one from Egypt, the other from Cappadocia. There is evidence that both were disciples of Lucian of Antioch, 'fellow Lucianists'. ${ }^{16}$ But precisely what this means is subject to debate, if it means much of anything at all; the claim does not necessitate any literary or personal contact between them, let alone theological

13 Markus Vinzent cites De decretis 8 and 20, and writes that Asterius is 'perhaps ... the precursor for Arius ... Athanasius twice emphasizes that Arius "transcribed" Asterius, or rather that Arius learned from him; in contrast, he never claims of Asterius that he borrowed from Arius' ( 'ist ... veilleicht ... der Vordenker für Arius. ... Athanasius nennt ihn stereotyp den "Anwalt der Häresie" und ihm, so betont er zweimal, habe Arius "nachgeschreiben" bzw. von ihm habe Arius gelernt; ungekehrt behauptet er von Asterius nie, er habe bei Arius Anleihen genommen'): Asterius von Kappadokien: die theologischen Fragmente, Leiden 1993, 22. See also p. $25^{6}$.

${ }^{14}$ For example, Vinzent, Asterius, 31-2. Vinzent's claim has been noted by others, but has not generated any substantial comment. Sara Parvis writes without further comment, 'Vinzent sees Asterius as the main theologian and teacher of all the Eusebians, including Arius': Marcellus of Ancyra and the lost years of the Arian Controversy, 325-345, Oxford 2006, 115 . Winrich Löhr states that 'Vinzent's claim that Arius was a disciple of Asterius cannot be discussed in this paper': 'Arius reconsidered (part 2)', 133 n. 38 .

${ }^{15}$ It would be methodologically problematic to dismiss De decretis 8.1 and 20.2 as polemical or rhetorical fabrications when other similar passages - such as De synodis 15.2 (whose significance is discussed below) - have been largely accepted as credible. As a matter of procedure, the precious bits of historical evidence in De decretis, De synodis and elsewhere in ancient sources must be accepted as reliable unless there is good reason for not doing so, such as patent contradictions with other more compelling evidence, if there it to be any hope of recovering the history of the early controversy over Arius.

${ }_{16}$ In his letter to Eusebius of Nicomedia (Urk 1 [Opitz edn, 3]), Arius calls him 'my

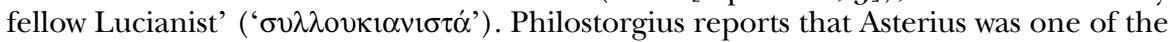
disciples of Lucian: Historia ecclesiastica 2.14. 
sympathies or borrowings. ${ }^{17}$ So if it is taken for granted that Arius did learn from Asterius, how did this happen? How can we make sense of the evidence of De decretis 8 and 20? I suggest that in the composition of his Thalia, Arius drew upon the Syntagmation of Asterius, demonstrating Arius' active involvement in the articulation of Eusebian theology in response to Asterius' tract in support of himself. And furthermore I suggest that both documents belong to a relatively late stage of the preNicene controversy over Arius, making it impossible that Asterius was responsible for the fundamental character and orientation of his theology. The influence of Asterius upon Arius must be understood in terms of refinement and nuance in presentation, not his basic theological orientation and vision.

\section{The De decretis passages}

In De decretis 7 Athanasius refutes the idea that 'the Father alone personally

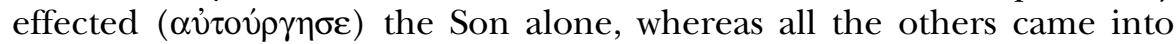

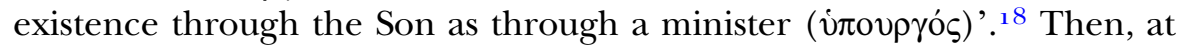
the beginning of De decretis 8, he grants this position for the sake of argument, writing:

If it is true that the rest of the creatures could not endure the exertions of the untempered hand of the unbegotten, then the Son alone came into existence by God alone and the others came into existence through the Son as through a minister and assistant. Indeed, this is what Asterius who sacrificed wrote, and Arius having copied it gave it to his own people. And from that time these deranged men use this catchphrase, though it be a shattered reed, unaware of the unsound idea that it contains. ${ }^{19}$

${ }_{17}$ The classic study of the Lucianists is Bardy, Recherches. See also Williams, Arius, 162-7; Hanson, The search, 79-83; and Hanns Christof Brennecke, 'Lukian von Antiochien in der Geschichte arianischen Streites', in Hanns Christof Brennecke, Ernst Ludwig Grasmück and Christoph Markschies (eds), Logos: Festschrift für Luise Abramowski zum 8. Juli I993, Berlin-New York 1993, 170-92. It is not clear precisely what connected all those called Lucianists. The general conclusion is that Lucian's teaching is largely enigmatic and that the doctrinal connections between his disciples are sufficiently diffuse, such that we cannot detect a cohesive theological tradition to which all Lucianists belonged. Rather, 'Lucianist' describes a group loosely connected by reverence for Lucian, however differently each Lucianist may have viewed or appropriated his master.

18 Athanasius, De decretis 7.1 (Opitz edn, 6.26-7).

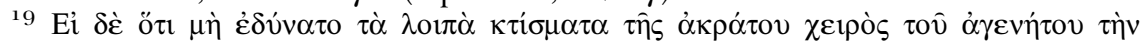

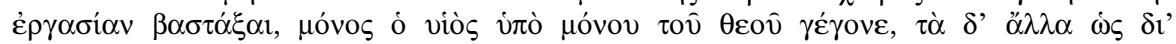

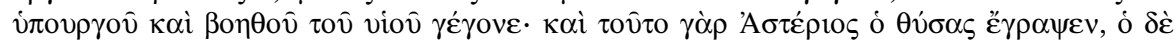

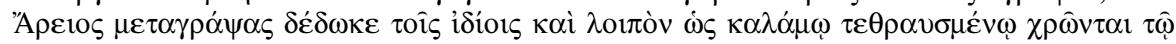

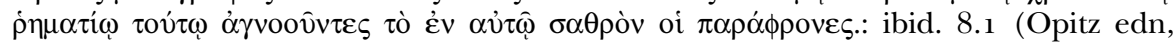
7.18-22). 


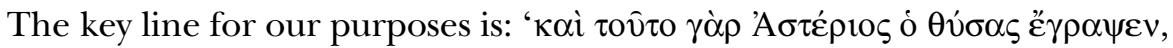

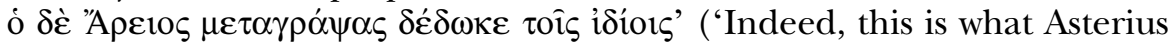
who sacrificed wrote, and Arius having copied it gave it to his own people'). ${ }^{20}$ The demonstrative pronoun $\tau$ ov $\tau$ o is the grammatical object of the three verbs (ž $\gamma \rho \alpha \psi \varepsilon v, \mu \varepsilon \tau \alpha \gamma \rho \alpha \dot{\psi} \psi \alpha \varsigma$, and $\delta \varepsilon \dot{\delta} \omega \kappa \varepsilon$ ), and refers to the idea or doctrine just described in De decretis 7 and 8.1. As for $\mu \varepsilon \tau \alpha \gamma \rho \alpha ́ \phi \omega$, here and elsewhere Athanasius uses it to mean 'to transcribe a copy, to make one copy from another'. ${ }^{21}$ Thus Athanasius is not merely saying that Arius 'copied' the idea in the sense of 'borrowed' or 'adopted from', but that he 'transcribed' it, that is, produced one written text from another. ${ }^{22}$ In other words, Athanasius affirms a literary relationship between Asterius and Arius, not merely a doctrinal one.

In addition, Athanasius has identified a 'catchphrase' that was included in a writing of Asterius (surely the Syntagmation, the only Asterian writing known to Athanasius), copied by Arius, and given to his people, whom Athanasius describes as 'deranged men' who used it 'unaware of the unsound idea that is contains'. The term 'catchphrase' ( $\dot{\eta \mu \alpha ́} \tau 10 v)$ was frequently used by Athanasius to describe phrases which he believed encapsulated Arian views. ${ }^{23}$ It is hard to determine whether Athanasius assigned a precise content to the catchphrase in this instance, but it stands for and summarises the Asterian teaching that he just described. In any case, Athanasius objects to calling the Son a minister and assistant because of those terms' negative theological implications (at least in his interpretation of the language). Such an idea and its attendant terminology, Athanasius claims, is found in the writing of Asterius, and Arius copied the idea, and possibly its attendant terminology, from Asterius in his writing, and thereby taught it to his supporters.

One might object that Athanasius uses $\mu \varepsilon \tau \alpha \gamma \rho \alpha ́ \phi \omega$ simply to vary his language, and by it he means nothing more than that Arius 'wrote' the same thing that Asterius did, that is, that Arius' Thalia contained the same idea as found in the Syntagmation. Indeed, this is how Athanasius speaks of the relationship between Arius and Asterius in the Orationes contra Arianos. In

${ }^{20}$ Ibid. (Opitz edn, 7.20-1). In a note Optiz says that 'Es fällt auf, daß Asterius als der Vorgänger des Arius bezeichnet wird' and cross-references De decretis 20.2.

${ }_{21}$ Epistula ad Serapionem de morte Arii 5.1 ; Epistula ad monachos 3.3.

${ }^{22}$ John Henry Newman published two different translations of Athanasius' antiArian works. In the present case, in both his original and revised translations, he translated this verb as 'has transcribed'. See his Select treatises of s. Athanasius in controversy with the Arians, translated with notes and indices, Oxford 1842, 13, and Select treatises of s. Athanasius in controversy with the Arians, freely translated, 4th edn, London 1887, 22. The well-known translation of De decretis in NPNF 2nd ser. iv is but Archibald Robertson's slight revision of Newman's.

${ }^{23}$ For example, De decretis 18.1; 18.2; De synodis 36.4; 39.4; Epistulae ad Serapionem $1.21 .2 ; 1.21 .4$. 
Orationes contra Arianos 2.37 Athanasius suggests literary parallels between the Thalia and the Syntagmation, without suggesting influence in either direction. After describing how the Arians believed in multiple wisdoms and words, Athanasius wrote: 'These things they have not only been quick to express in speech, but Arius composed in his Thalia and the sophist Asterius wrote that which we just stated above, as follows.' 24 What follows is an undisputed fragment of the Syntagmation, which Athanasius attributed solely to Asterius on two other occasions in his corpus. ${ }^{25}$ It is unlikely that Athanasius meant that the same passage was also found verbatim in the Thalia. Instead, the Asterian fragment is cited as textual evidence that the Arians taught multiple wisdoms and multiple words. The same doctrine, suggests Athanasius, was also found in the Thalia. But here Athanasius does not claim that Arius copied or learned this from Asterius. The best interpretation of this passage is that it is an expression of Athanasius' concept of Arianism: since the same heretical doctrine is found expressed in all their writings (the Thalia, the Syntagmation, etc.), then any of their texts can be used to present the tenets of Arianism. The same idea is expressed elsewhere in the Orationes, where Eusebius of Nicomedia is included among those who wrote similar things. ${ }^{26}$ So it seems improbable that in De decretis 8 Athanasius used $\mu \varepsilon \tau \alpha \gamma \rho \alpha \dot{\phi} \omega \omega$ as a synonym for 'wrote', given his usage of the verb elsewhere and the recognised usage of the verb in other authors. ${ }^{27} \mathrm{By}$ the use of $\mu \varepsilon \tau \alpha \gamma \rho \alpha \dot{\phi} \omega$ Athanasius is suggesting something quite different about the relationship between Arius and Asterius in De decretis 8.1 than in Orationes contra Arianos 2.37.

Now on to De decretis 20. This passage does not suggest a literary relationship as clearly as the first passage from De decretis does, but it is at least implied. In De decretis 20.1-2 Athanasius relates how the Eusebians claimed that certain scriptural expressions were common to human beings and the Son, thereby indicating that the Son was ontologically on a par with humans:

Again, the bishops [at the Council of Nicaea] said that the Word must be described as the true power and image of the Father, as in every respect like the Father and indistinguishable from him, as immutable and always in him without division. For never was the Word not, but rather he was always existing eternally with the Father,

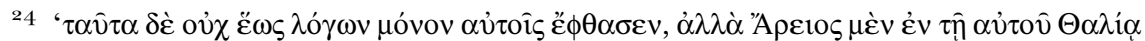

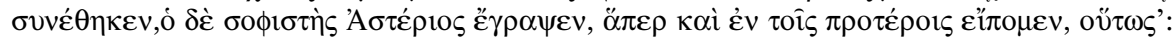
Orationes contra Arianos 2.37, 7-9 (Metzler/Savvidis edn, 214).

25 Orationes contra Arianos 1.32; De synodis 18.

26 'These things they have not only said, but also dared to write, namely, Eusebius and Arius and Asterius who sacrificed': Orationes contra Arianos 2.24, 28-9 (Metzler/ Savvidis edn, 20).

${ }^{27}$ See the range of usage in Henry George Liddell, Robert Scott, Henry Stuart Jones and Roderick McKenzie, A Greek-English lexicon, 9th edn with a revised supplement, Oxford 1996, and G. W. H. Lampe, A patristic Greek lexicon, Oxford 1961. 
as radiance does with light. [After all this was said] the Eusebians restrained themselves, not daring to contradict it because of their shame over being refuted. And yet once again they were caught babbling and making signals to each other with their eyes, [saying] that, on the contrary, the 'like' and the 'always' and the name 'power' and 'in him' are common to us and the Son, and that it does us no harm if we agree with them. As for 'like', because about us it is written: Man is the image and glory of God [ 1 Corinthians xi.7]. As for 'always', because it is written: Always while we live [2 Cor. iv.11]. As for 'in him', because in him we live and move and have our being [Acts xvii.28]. And as for 'immutable', because it is written: Nothing shall separate us from the love of Christ [Romans viii.35, 39]. With regard to 'power', because the caterpillar and the locust are called a power and a great power [Joel ii.25]. And again because it is often used for people, for instance: All the power of the Lord came out of the land of Egypt [Exodus xii.41]. And furthermore because there are other heavenly powers, for it says: the Lord of powers is with us; the God of Jacob is our stronghold [Psalm xlv.8]. ${ }^{28}$

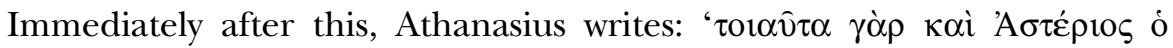

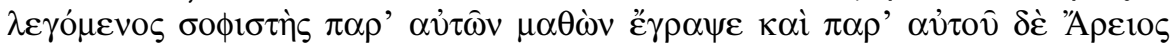

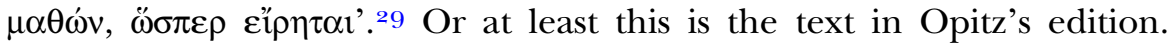

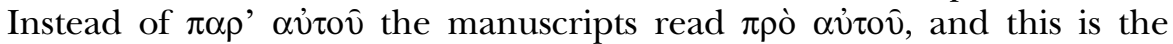
reading in the 1698 Maurist edition, which was reprinted in Migne. $3^{\circ}$ Accordingly, the well-known NPNF translation-which is in fact John Henry Newman's translation, which itself was based on the Benedictine edition - reads: 'Indeed Asterius, by title the sophist, had said the like in writing, having learned it from them, and before him Arius having learned it also, as has been said.'31 Opitz emended the Greek text based on a

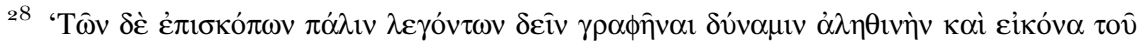

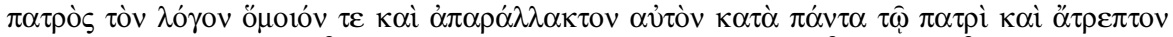

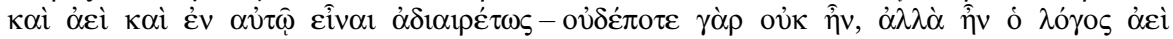

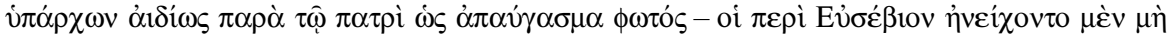

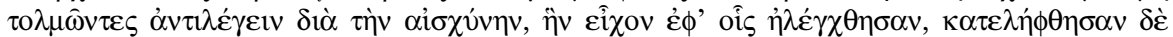

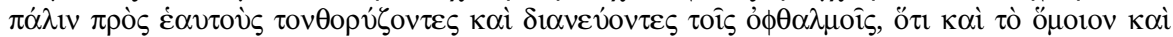

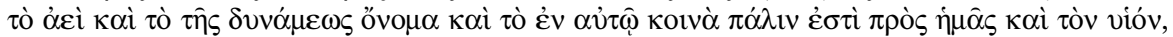

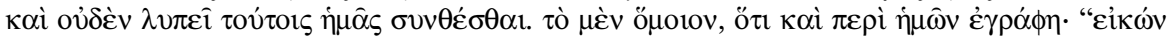

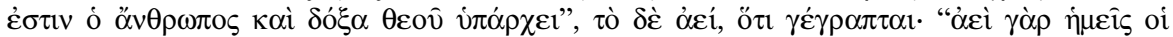

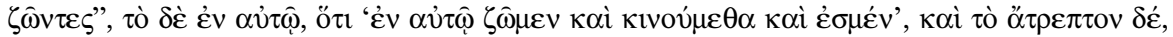

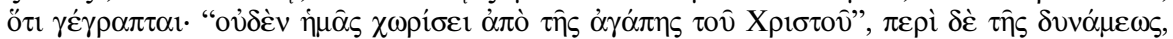

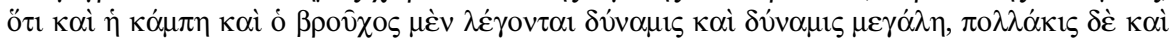

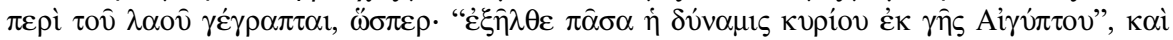

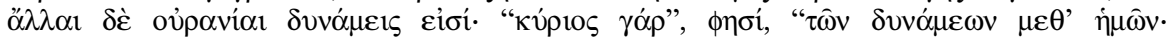

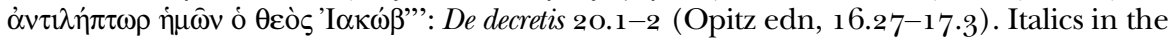
translation indicate scriptural citations.

${ }^{29}$ Ibid. 20.2 (Opitz edn, 17.3-5). $3^{\circ} P G$ xxv. $45^{2}$.

${ }^{31}$ NPNF ii.4. 163; Newman, Select treatises ... freely translated, 38 . Newman's original translation had 'having taken' instead of 'having learned' in both instances: Select treatises ... translated with notes and indices, 35 . 
conjecture of Tillemont, who held that the manuscript reading made no sense. This alternate reading, he claimed, made better sense of the passage, restored a parallel construction ( $\pi \alpha \rho$ ' $\alpha \dot{\tau} \tau \hat{\omega} v \mu \alpha \theta \dot{\omega} v \quad \ldots \quad \pi \alpha \rho$ '

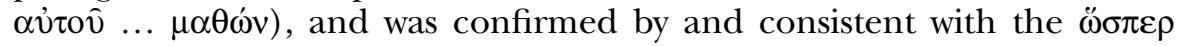
Eip $\eta \tau \alpha$, which Tillemont took to refer back to De decretis $8.3^{2}$ The Tillemont-Opitz emendation has not been contested, and I accept it too. 33

Basing himself on the Opitz edition Khaled Anatolios rendered the key line as follows: "Asterius, who is called "the sophist", has written these things, having learned from them and, along with him, Arius also, as has been said.' 34 But it seems that the prepositional phrases with $\mu \alpha \theta \dot{\omega} v$

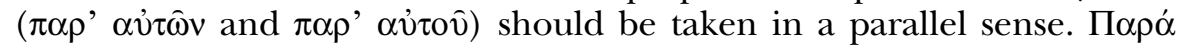
plus the genitive denotes source from which, not coincidence as in Anatolios's translation. Accordingly, the translation should be: 'Now such things Asterius the so-called sophist wrote, having learned from them and Arius having learned from him, as has been said.' I contend as well that the sole indicative verb of the sentence, है $\gamma \rho \alpha \psi \varepsilon$, also applies to Arius, as in: 'and Arius [wrote], having learned from him'. Accordingly, Athanasius is again suggesting a literary relationship between Arius and Asterius, even if not as clearly and explicitly as in De decretis 8 . Athanasius is also alluding to a kind of heretical succession: from the Eusebians through Asterius to Arius. 35 What Asterius learned from the Eusebians he wrote down: surely the Syntagmation is again meant. And then what Arius learned from Asterius - via the Syntagmation - he wrote.

One final detail of the key line from De decretis 20 is relevant: 'as has been

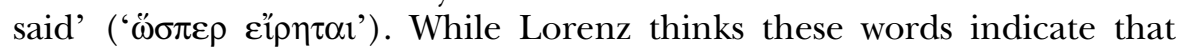
Athanasius is basing his statement on hearsay, both Tillemont and Opitz take them as a reference back to De decretis $8.3^{6}$ A survey of Athanasius'

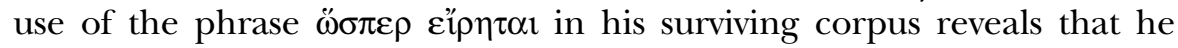
uses it to refer back to a previous statement or idea; thus the interpretation of Tillemont and Opitz appears to be correct. 37 Accordingly, this phrase provides additional proof that Athanasius is positing a literary relationship between Arius and Asterius in section 20, just as in De decretis 8.

$3^{2}$ Tillemont, Mémoires, vi. $75^{1}$ n. 21 . Bardy endorsed the emendation too: Recherches, 321.

33 F. Scheidweiler, 'Zur neuen Ausgabe des Athanasios', Byzantinische Zeitschrift xlvii (1954) , 73-94; E. Cattaneo, 'Alcune proposte di correzione al testo del "De decretis" di Atanasio', Adamantius viii (2002), 24-32; Athanasius Werke, II/1: Die Apologien, Lieferung 8, ed. H. C. Brennecke, U. Heil and A. von Stockhausen, Berlin-New York 2006, pp. xci-xcvii.

34 Khaled Anatolios, Athanasius, London 2004, 197.

35 Vinzent, Asterius, $25^{6 .}$

${ }^{36}$ Lorenz, Arius judaizans?, 191; Tillemont, Mémoires, vi. $75^{1}$ n. 21 ; Opitz, Die Apologien, 17 (note on line 4 ).

37 According to the Thesaurus linguae Graecorum database, the phrase is used thirtytwo times in his works. 
In both passages Athanasius surely makes reference to the Syntagmation, the only writing of Asterius that he knew. He indicates that he considers the text both at least in part inspired by the Eusebians and in some sense used by Arius in a writing. It was in Thalia that Arius drew upon the Syntagmation.

\section{The Thalia and Syntagmation}

Little is known about the circumstances of each document. A key passage for understanding the composition of the Thalia is found in De synodis 15 , where Athanasius introduces and preserves the longest extant fragment of it..$^{8}$ Here Athanasius first lists four catchphrases which he claims sums up the teaching of Arius and his colleagues, on the basis of which they were expelled $(\dot{\varepsilon} \xi \varepsilon \beta \lambda \eta \dot{\theta} \theta \eta \sigma \alpha v)$ by Alexander from the Alexandrian church.39 Then Athanasius writes a sentence that has proved difficult to interpret:

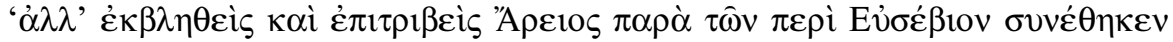

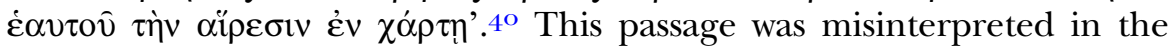
well-known English translation by Archibald Robertson in the NPNF series, from 1891: 'However, after his expulsion, when he was with Eusebius and his fellows, he drew up his heresy upon paper.' ${ }^{4}$ The

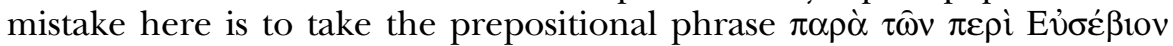
temporally. Robertson's translation is but a revised version of Newman's English translation, both versions of which contain the same misinterpretation. $4^{2}$ In fact, this misinterpretation ultimately goes back to Petrus Nannius' Latin translation of 1556 and was repeated in the 1698 Maurist

$3^{8}$ I am not persuaded by Charles Kannengiesser's proposal that the 'blasphemies of Arius' in De synodis 15 are a neo-Arian updating of Arius from the $35^{\mathrm{os}}$. He first advanced this thesis in his Holy Scripture and hellenistic hermeneutics in Alexandrian Christology, Berkeley 1982, $15^{-7}$, but his most extensive attempt to prove it is his 'The blasphemies of Arius: Athanasius of Alexandria, De synodis 15', in Robert C. Gregg (ed.), Arianism: historical and theological reassessments, Philadelphia $198_{5}, 59-8_{3}$. For the case against Kannengiesser see the objections of Thomas A. Kopecek, 'Professor Charles Kannengiesser's view of the Arian crisis: a critique and counter-proposal', in Kannengiesser, Holy Scripture and hellenistic hermeneutics, 51-68 at 53-7, as well as Rowan Williams, 'The quest of the historical Thalia', in Gregg, Arianism, 1-35 at pp. 2-19. Kannengiesser's thesis has not found acceptance among scholars.

39 De synodis 15.1 (Opitz edn, 242.1-4). $\quad 4^{\circ}$ Ibid. 15.2 (Opitz edn, 242.4-5).

$4^{1} \quad N P N F$ ii, $4 \cdot 457$.

$4^{2}$ 'However, after his expulsion, when he was with the Eusebians, he drew up his heresy upon paper': Newman, Select treatises ... translated with notes and indices, 94. This translation was published in 1842. Newman's later 'free translation' from 1887 retains the same interpretation but with a revised translation: 'However, Arius after his expulsion, when he was living near the party of Eusebius, drew up his heresy upon paper': Select treatises ... freely translated, 82 . 
translation. 43 With the prepositional phrase interpreted in this way, for centuries the passage was used as evidence that Arius resided in Nicomedia for a while and composed the Thalia there.44

This traditional interpretation has been challenged by William Telfer, Charles Kannengiesser and Rowan Williams. Telfer pointed out that it was mistaken on two counts: (1) because it takes $\pi \alpha \rho \alpha ́$ + the genitive as indicating 'rest at' instead of 'agent by whom', and (2) because it treats $\varepsilon \dot{\pi} \imath \tau \uparrow ß \varepsilon i \zeta$ as if it were $\delta 1 \alpha \tau \rho i \beta \omega v .45$ Telfer suggested a rendering that is more grammatically plausible: 'Nevertheless, Arius, thrown over and distressed by the Eusebian gang, committed his own heresy to writing.' According to his interpretation, Arius was rejected by Eusebians and, desperate at losing their endorsement, he composed the Thalia (in Alexandria) to shore up his Egyptian support. Thus, according to Telfer, the Thalia is a document that makes no concessions to Eusebian concerns; in it there is no 'common ground' between Arius and the Eusebians; it is meant to appeal to a local Egyptian audience.

Though Charles Kannengiesser agreed with Telfer's critique of the traditional interpretation, he rejected Telfer's too, suggesting 'Mais, jeté dehors et poussé par les Eusébians, Arius consigna sa propre hérésie par écrit - But, thrown out and pushed by the Eusebians, Arius put his own heresy in writing.' Kannengiesser's interpretation suggests that Arius composed the Thalia at the instigation of the Eusebians as a direct reply to his excommunication by Alexander. Thus Kannenegiesser detects a causal connection between the two participles - his being 'thrown out' leads the Eusebians to 'push' him to write. According to Kannengiesser, then, Arius composed the Thalia after his ecclesiastical excommunication but while still in Alexandria, at the prompting of the Eusebians, precisely to bring his conflict with Alexander to a head. ${ }^{6}$ And this ploy was successful, since it led to Alexander banishing Arius from Alexandria after publishing the Thalia. But, as Rowan Williams has noted, this interpretation seems

43 Nannius: 'Ariumque ita ab Ecclesia summotum, dum apud Eusebium commoraretur'; Maurists: 'Ejectus autem Arius dum apud Eusebium versaretur.' On the history of this misinterpretation see William Telfer, 'Arius takes refuge at Nicomedia', JTS n.s. xxxvii (1936), 59-63 at p. 61, and Charles Kannengiesser, 'Où et quand Arius composa-t-il la Thalie?’, in P. Granfield and J. A. Jungmann (eds), Kyriakon: Festschrift Johannes Quasten, Münster 1970, $34^{6-} 5^{1}$ at pp. 346-7. The Latin texts are cited from Kannengiesser, 'Où et quand', 346 .

44 For example, Bardy, Recherches, 246; Frances M. Young with Andrew Teal, From Nicaea to Chalcedon: a guide to the literature and its background, 2nd edn, Grand Rapids, Mi 2010, 44. Epiphanius, Panarion 68.4.4; 69.5.3; and 69.7.1 also posit a residence in Nicomedia. 45 Telfer, 'Arius takes refuge', 61 .

$4^{6}$ The phrase 'bring to a head' is from Williams, 'The quest', 19. 
unlikely since the Eusebians worked to persuade Alexander to restore Arius to communion, not to exacerbate the quarrel for political ends. 47

Williams considered Telfer's interpretation grammatically sound but historically implausible (since a breach between Arius and the Eusebians would surely have been exploited by their opponents) and Kannengiesser's less grammatically sound and historically unlikely. None the less, Williams follows Kannengiesser in the only translation he offers: 'After his excommunication, Arius, under pressure from the Eusebian party, committed to writing a summary of his heresy.' He also explored the possibility of construing the prepositional phrase with the main verb

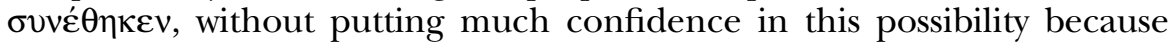
of its grammatical awkwardness. He offered four increasingly speculative renditions: Arius put his own heresy in writing 'from the Eusebian camp, from the Eusebian point of view, at the prompting of the Eusebians, arising from the agency of the Eusebians'. Williams declined to offer his own definitive translation, considering the gist of the passage clear enough: Arius composed the Thalia with the encouragement of the Eusebians. He suggests this scenario: some time after Arius had won the initial support of the Eusebians, when the excommunicated Arius had relocated to Palestine, more detailed reports of Arius' teaching began to trouble at least some of those Eusebians who had initially supported him. The Eusebians then encouraged Arius to clarify his position. Williams suggests, then, that Arius composed the Thalia in Palestine (after the synod of one hundred in Alexandria) to reassure the Eusebians of his basic theological agreement with them. In other words, the Thalia is a document to shore up and recover Eusebian support. $4^{8}$ Following Rowan Williams, I translate the passage thus: 'After his expulsion, Arius, at the prompting of the Eusebians, put down his own heresy on paper.'

But is this passage receptive of another interpretation besides that of Williams? The passage might mean that when Arius intially sought the support of the Eusebians, they asked him to clarify his views. Perhaps the participles joined by the co-ordinate conjunction kai specify the proximate conditions under which Arius composed the Thalia, events which happened in quick succession. Following Kannengiesser, it may well be the case that it was the excommunication itself that led the Eusebians to request from Arius a fuller statement of his theology, but not for the reasons that Kannengiesser thought. Perhaps something like this

47 Ibid. 19-20.

$4^{8}$ Ibid. 20-3, and Arius, 63-5. Other scholars also interpret Athanasius' comments in De synodis 15.2 as evidence that Arius composed his Thalia as a theological clarification for those Eusebians still uncertain whether to support him in his conflict with Alexander: Stuart Hall, 'The Thalia of Arius in Athanasius' accounts', in Gregg and Groh, Arianism, $37^{-} 5^{8}$ at p. $4^{\text {o. }}$ 
happened. The excommunication led Arius to seek support among Eusebian bishops. They may not have been so keen on Alexander's actions and theology, but still they were wary of endorsing an officially excommunicated heretic. And so they asked Arius to state his views more precisely to help them decide if his cause was really worth defending. If this interpretation is correct, then the Thalia is earlier than Williams thought, and furthermore it is not a document written to recover, but rather to win Eusebian support.

But there is a major problem with using the passage in De synodis 15.2 to support the hypothesis that the Thalia was written at an earlier date to win Eusebian support: there is no way that Arius could have copied from Asterius at this point, and thus the evidence of De decretis 8 and 20 would have to be disregarded. Only if the Syntagmation was written prior to the Thalia could Arius have copied from Asterius. Admittedly, information on the circumstances of the composition of the Syntagmation is scarce. 49 Athanasius describes this handbook as 'quite long' $5^{\circ}$ and as articulating the theological views of the 'Arians', that is, the Eusebian alliance. $5^{1} \mathrm{~A}$ pre-Nicene date has been consistently endorsed by scholars. $5^{2}$ The only passage that hints at its origin is found in De synodis 18, where Athanasius introduces a series of fragments from the work. He writes that Asterius 'pro-

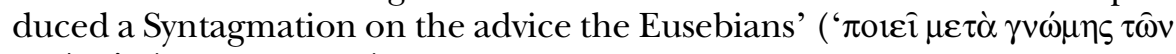

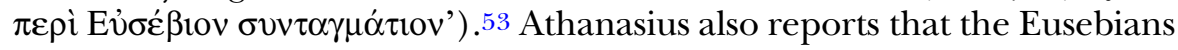
sent Asterius on a kind of 'book tour' to promote their cause, during which he travelled around the churches of the East giving public readings of his

49 In fact, we do not even know its original title. Athanasius calls Asterius' work a

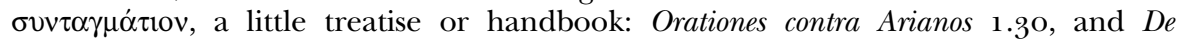
synodis 18.2 , as well as Bardy, Recherches, $335^{-6}$. Even though this label probably indicates its genre, not its title, among scholars it is generally the custom to refer to it as the Syntagmation: Vinzent, Asterius, 33 .

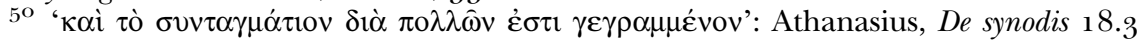
(Opitz edn, 245.31).

$5^{1}$ Athanasius, De synodis 18.2. See also Socrates, Historia ecclesiastica 1.36.2, who describes it as commending the doctrine of Arius.

$5^{2}$ For example, Bardy, Recherches, 320-2. Joseph Lienhard has tentatively suggested a more precise date of 320-1: Contra Marcellum, 91. That in De synodis 18-19 Athanasius is narrating pre-Nicene events is clear. In De synodis 17 he quotes from several letters written by members of the Eusebian alliance before the Nicene Council took place. De synodis 18-19 is thus devoted to quotations from the pre-Nicene writing of Asterius. In De synodis 20, Athanasius suggests that the views expressed by Asterius and the other Eusebians before the Council of Nicaea explain their resistance to it afterwards. He adds further that Asterius was put forward by the Eusebians as the advocate of their cause. In De synodis 21 Athanasius turns to the councils convened by the Eusebians after Nicaea. Socrates, Historia ecclesiastica $1.3^{6.3}$ is almost certainly dependent upon $D e$ synodis 18.2 (see Bardy, Recherches, 318 ), but he sees the 'book tour' as in support of his letter in defence of Eusebius of Nicomedia.

53 De synodis 18.2. Athanasius uses the same phrase in Apologia contra Arianos 6o.2. 
handbook.54 So it seems that the Syntagmation was written in support of Arius, to drum up support for the Eusebian cause among easterners. 55 Accordingly, it belongs to a stage of the controversy when Arius had been excommunicated by Alexander but had already convinced the Eusebian leadership to support him, and one of their means of doing so was to have Asterius write a theological response, the Syntagmation. The Syntagmation is thus roughly contemporary with the letter that Eusebius wrote to Paulinus of Tyre urging him to write to Alexander of Alexandria to protest against his excommunication of Arius, a request with which Paulinus complied. $5^{6}$

Certainty on chronological matters related to the controversy over Arius before Nicaea is elusive. But there is general agreement that at some point Arius relocated to Palestine and it was here that he wrote the extant letter to Eusebius of Nicomedia to secure his support. 57 Eusebius responded favourably, and became the champion of Arius. I suggest that both the Syntagmation and the Thalia belong to this stage of the controversy (which according to Williams's chronology would be 321-3). After he agreed to support Arius, in addition to writing to bishops such as Paulinus, Eusebius had Asterius write the Syntagmation in order to promote the cause of Arius throughout Syria by means of the 'book tour' (perhaps around 322). $5^{8}$ Williams sees the Alexandrian synod of a hundred bishops as a reaction to Eusebius' endorsement of Arius and the list of its signatories as evidence that 'many of Arius' initial supporters' among Syrian and Palestinian bishops 'were wavering'.59 If this is so, then Eusebius would have pushed Arius to write the Thalia to recover their support in its wake (perhaps around 323 ).

If this reconstruction is correct, the Thalia was written after the Syntagmation, and thus Arius could have borrowed, that is, copied from Asterius. This is speculative. But the merit of this interpretation is that it accounts for all the Athanasian evidence, De decretis 8 and 20 as well as $D e$

54 De synodis 18.2 .

55 A few fragments implicitly suggest that the Syntagmation was polemical, because in them Asterius seems to reject interpretations of Scripture and theological ideas of unspecified opponents. The clearest examples include Orationes contra Arianos 1.32 (also cited in 2.37 and De synodis 18); 2.40; 3.2; and 3.6o, as well as De synodis 19.3.

$5^{6}$ Urk 8, 9. The letter to Paulinus was the first in a series of documents that most convincingly demonstrate the activity of mutual defence among the Eusebians. Aside from Paulinus' letter to Alexander, at some point after the Council of Nicaea Asterius penned his Apologia in defence of Eusebius' letter to Paulinus. In response Marcellus of Ancyra attacked not only Asterius, but also Eusebius of Caesarea, Eusebius of Nicomedia, Paulinus of Tyre and Narcissus of Neronias - all key members of the Eusebian alliance. In turn, Eusebius of Caesaera wrote two works against Marcellus: Contra Marcellum and De ecclesiastica theologia.

57 Urk 1.

$5^{8}$ Williams, Arius, 57.

59 Ibid. 
synodis 15 and 18 . Other interpretations, such as for a composition of the Thalia while Arius was still in Alexandria, would have to discount some of it. ${ }^{60}$ This interpretation also further complicates the literary relationship between Arius and Asterius: Arius is both an impetus for and influenced by the Syntagmation. This makes it even harder to disentangle the thought of Arius and Asterius in the works of Athanasius. But it is clear that Asterius can by no means be considered a formative influence on Arius. His influence on Arius came late in the controversy; it is more a question of intellectual refinement than fundamental formation.

Futhermore, if this reconstruction is correct, we come away with a better understanding of the original context of the Syntagmation. In the wake of Arius' winning the support of Eusebius of Nicomedia around 321, it was mostly likely written at the urging of the Nicomedian bishop to promote the cause of the mistreated and misunderstood Alexandrian presbyter among eastern churchmen. It was part of a literary campaign that included the well-known letter of Eusebius to Paulinus, a letter that within a few years Asterius himself defended in his Apologia.

Finally, if this reconstruction is correct, it demonstrates that Arius was an important interlocutor within the newly formed Eusebian alliance and played a pivotal role in its efforts to clarify its position. Arius sparked the emergence of the Eusebian alliance by securing the support of Eusebius of Nicomedia, who then promoted his cause throughout the eastern provinces. A key element of his endorsement of Arius was commissioning Asterius to write the Syntagmation, upon which Arius then drew to bolster support of himself when writing the Thalia. This activity of mutual defence would continue among the Eusebians, even if Arius himself soon became marginalised. The relationship between Arius' Thalia and Asterius' Syntagmation as reconstructed here thus provides strong evidence for the recent revisionist view of Arius.

6o For example, Lorenz dismisses the evidence of De synodis 15 as sheer polemic ('bloße Polemik') because it contradicts his early date for the Thalia: Arius judaizans, 5 2. 